Jayakody et al. /Journal of Tropical Forestry and Environment Vol. 9, No. 02 (2019) 93-100

\title{
Composition analysis of selected Sri Lankan seaweeds
}

\author{
M.M Jayakody ${ }^{1}$, M.P.G Vanniarachchy ${ }^{1 *}$, I. Wijesekara ${ }^{1}$ \\ ${ }^{1}$ Department of Food Science \& Technology, Faculty of Applied Sciences, University of Sri \\ Jayewardenepura, Gangodawila, Nugegoda, Sri Lanka
}

Date Received: 12-11-2018

Date Accepted: 20-12-2019

\begin{abstract}
Seaweeds are a rich source of health beneficial bioactive nutraceuticals and currently they are under-utilized in Sri Lanka. In the present study, proximate analysis of seaweed varieties Chnoospora minima and Porphyra sp. obtained from Mirissa, Matara, Sri Lanka and Ulva fasciata was taken from Point Dondra Matara, Sri Lanka on June, 2018 were investigated. The moisture content, total fat content, protein content and ash content were determined according to the Official methods of Analysis by Association of Official Analytical Chemists after drying for $8 \mathrm{~h}$ at $60^{\circ} \mathrm{C}$. The results revealed that the moisture contents (\%) of Chnoospora minima, Porphyra sp. and Ulva fasciata were $13.24 \pm 0.20,14.30 \pm$ 0.14 and $18.11 \pm 0.01$ respectively. Total fat contents (\%) of Chnoospora minima, Porphyra sp. and Ulva fasciata were $0.21 \pm 0.11,0.19 \pm 0.03$ and $0.28 \pm 0.05$ respectively. Protein contents $(\%)$ of Chnoospora minima, Porphyra sp. and Ulva fasciata were $13.70 \pm 0.2,21.14 \pm 0.04$ and $11.84 \pm 0.1$. Total ash contents (\%) of Chnoospora minima, Porphyra sp. and Ulva fasciata were $17.20 \pm 0.24,5.40 \pm 0.7$ and $18.05 \pm 0.21$ respectively. Total carbohydrate content $(\%)$ was analyzed according to the Dubois method. Chnoospora minima, Porphyra sp. and Ulva fasciata showed total carbohydrate content (\%) as $3.87 \pm$ $0.66,20.59 \pm 0.24$ and $7.68 \pm 1.16$ respectively. Moreover, the sulphate content was analyzed according to the precipitate method. Chnoospora minima, Porphyra sp. and Ulva fasciata showed $1.45 \pm 0.35,2.75$ \pm 0.07 and $4.54 \pm 0.06$, sulfate contents $(\%)$ respectively. In conclusion, highest ash content which indicates a good mineral content was observed in Ulva fasciata and Chnoospora minima. Fibre, protein and carbohydrate contents are significantly different among the 3 samples. Highest fibre content was observed in Chnoospora minima. Highest protein and carbohydrate contents were observed in Porphyra $s p$. But there is no significant difference in fat contents among the three samples.
\end{abstract}

Keywords: Chnoospora minima; Porphyra sp.; Ulva fasciata; proximate analysis; sulphur

\section{Introduction}

At present people are seeking more benefits from foods other than satisfying their hunger. Thus the role of food in human health is gaining more attention over the last few years (Gupta and AbuGhannam, 2011). In that case, since seaweeds are an underutilized abundant food resource in Sri Lanka seaweed based products can be introduced as a good choice for consumption. The beneficial effects of food can be attributed to different compounds present in foods such as phenolic compounds, sulphated polysaccharides and organic acids which possess antioxidants, antimicrobial, antiviral and anticancer activity (Gupta and Abu-Ghannam, 2011). Though the chemical composition of seaweeds is not well known as the terrestrial plants but it is known to be rich in carbohydrates, protein and minerals as well as bioactive compounds such as polyphenols, terpenoids, carotenoids and tocopherols. Seaweeds have been also reported to produce a great variety of metabolic compounds which are not produced by terrestrial plants. Bioactive compounds which have been isolated and identified from seaweeds include sulphated polysaccharides (laminarins and fucoidans), polyphenols such as phlorotannins carotenoid pigments such

*Correspondence: mihiripg@sjp.ac.lk, 
as fucoxanthin and astaxanthin, sterols and mycosporine-like amino acids. (Gupta and Abu-Ghannam, 2011).

Generally seaweeds can be classifies in to 3 main groups according to their pigmentation as brown (Phaeophyta), red (Rhodophyta), and green (Chlorophyta) seaweeds (Chan, Ho and Phang, 2006). Seaweed is a food source which contains protein, lipids, vitamins and minerals. It is stated that this nutrient content varies depending on the type of species, the time of collection, geographic habitat, and ambient conditions such as water temperature and light intensity as well as nutrient concentration in water (Marsham, Scott and Tobin, 2007).

Studies have been revealed that seaweeds are rich with polysaccharides. These seaweed polysaccharides cannot be entirely digested by human intestinal enzymes. Hence they are regarded as fibre rich food ingredients. Together with their low lipid content, seaweeds only provide a very low amount of energy. Consumption of seaweeds can increase the intake of dietary fiber and lower the occurrence of some chronic diseases (diabetes, obesity, heart diseases, cancers), which are associated with low fiber diets (Wong and Cheung, 2000). The protein in algae contains all the essential amino acids. (Dawczynski, Schubert and Jahreis, 2007). Matanjun et al., 2008 has also stated that, seaweeds contain all the essential amino acids in different proportions, except for tryptophan, which was destroyed during hydrolysis. Thus the present study has done to get a general idea about the nutritional composition of Chnoospora minima, Porphyra sp. and Ulva fasciata available in southern cost of Sri Lanka.

\section{Methodology}

\subsection{Sample collection}

The seaweed samples of Porphyra sp. and Chnoospora minima seaweed varieties were manually collected during June, 2018 from Mirissa, Matara district, Sri Lanka (5'56'53.74" (5.9482 ${ }^{\circ}$ ))and $\left.80^{\circ} 28^{\prime} 17.71^{\prime \prime}\left(80.4715^{\circ} \mathrm{E}\right)\right)$ and Ulva fasciata from Point Dondra, Matara district, Sri Lanka $\left(5^{\circ} 55^{\prime} 7.9^{\prime \prime}\right.$ $\left(5.9189^{\circ} \mathrm{N}\right)$ and $80^{\circ} 35^{\prime} 24.8^{\prime \prime}\left(80.5902^{\circ} \mathrm{E}\right)$ ) All the algal samples were harvested manually from the respective locations and then transported to the laboratory in polythene bags. They were thoroughly cleaned to remove epiphytes and detritus attached to the fronds and kept in a freezer till further use.

Finally algal samples were dried at $60^{\circ} \mathrm{C}$, in a drying cabinet for 8 hours. Then they were pulverized into small particles, sieved through the 355 micron (Number 42) sieve. Then they were stored in room temperature, sealed in polypropylene bags till further used in analysis.

\subsection{Determination of moisture content}

Moisture content was determined by the infrared moisture analyzer (Shimadzu, Max 60g, $\mathrm{d}=0.001 \mathrm{~g}$ ) expressed as percentage by weight of sample.

\subsection{Determination of total ash (Gravimetric method)}

Total ash Content was determined according to the AOAC official method 923.03. Approximately 5g of the samples were weighed into previously cleaned, dried and weighed porcelain crucibles. Subsequently the samples were ignited slowly over a Bunsen flame until no more fumes evolved. The dishes were then transferred in to the muffle furnace (Wise therm) set at $550{ }^{\circ} \mathrm{C}$ and incinerated until it was free of black carbon particles and turns to white or grey in colour. The incinerated crucibles were cooled in the desiccator and the weight was recorded. Ashing, cooling and weighing procedures were repeated until the difference between two successive weights was less than $1 \mathrm{mg}$. Experiment was duplicated. Finally the total ash percentage was determined by the following equation; 
Jayakody et al. /Journal of Tropical Forestry and Environment Vol. 9, No. 02 (2019) 93-100

Ash \% $\quad=\quad$ Weight of ash

X 100

Weight of the sample

Ash $\% \quad=\quad \underline{m 3-m 1} \times 100$

$\mathrm{m} 2-\mathrm{m} 1$

$\mathrm{m} 1=$ Weight of the empty crucible

$\mathrm{m} 2=$ Weight of the crucible + sample before drying

m3 = Weight of the crucible + sample after drying

\subsection{Determination of protein content}

Protein content was determined by Micro Kjeldhal Method (AOAC method 978.04) with following 3 main steps. Those were acid digestion of samples, Distillation of the samples followed by titration. During acid digestion $50 \mathrm{mg}$ of the sample were measured on to a tissue paper and folded such that samples do not come out. Then the samples were digested separately at $420{ }^{\circ} \mathrm{C}$ for 3 hours in Kjeldhal digestion flasks with $2.5 \mathrm{ml}$ of Conc. $\mathrm{H}_{2} \mathrm{SO}_{4}$ and a Kjeldhal tablet. After digestion the contents in the digesting tubes were transferred to the tube in the distillation unit one by one while supplying $32 \% \mathrm{NaOH}$ and distilled water to the distillation unit. During the distillation, the emitted gas was collected to $5 \mathrm{ml}$ of $4 \%$ boric acid solution with few drops of Kjeldhal indicator in the medium. The gas trapped by $4 \%$ boric acid was titrated with $0.02 \mathrm{M}$ Standardized $\mathrm{HCl}$ and recorded the end point. Protein content of the seaweed samples were calculated by the following equation. The experiment was triplicated.

Nitrogen $(\%)=\underline{(\text { Sample titre }- \text { Blank titre }) \times \text { Molarity of } \mathrm{HCl} \times 14 \times 100}$

Weight of the sample taken $\mathrm{x} 1000$

Protein $\quad=$ Nitrogen $(\%) \times$ Factor

\subsection{Determination of lipid content (Soxhelt extraction method)}

Lipid content was determined by the soxhelt extraction method. Approximately $10 \mathrm{~g}$ of finely ground sample was weighed to the nearest $0.1 \mathrm{~g}$ into the motor and pestle and twice the weight of anhydrous sodium sulphate was added. The content was ground until a free flowing powder was obtained after which it was transferred in to the extraction thimble and covered with a cotton wool. The extraction thimble with the sample was placed in the soxhlet apparatus. A cleaned, dried and previously weighed round bottom flask $(250 \mathrm{ml})$ containing $200 \mathrm{ml}$ of petroleum ether with pumice chips and a condenser was connected to the soxhlet apparatus and refluxed for 5 hours keeping the heating rate low enough to prevent solvent escaping from the top of the condenser during the refluxing. After the refluxing was over, the solvent was distilled off and cooled the content with the flask and weighed. The process was repeated until a constant 
weight was obtained. Experiment was duplicated. The crude fat percentage of the sample was determined by the following equation,

Percentage of crude fat content of the sample $=\underline{\mathrm{W} 1-\mathrm{F}} \times 100$

\section{W2}

$\mathrm{W} 1=$ Weight of the flask with fat and chips.

$\mathrm{F}=$ Weight of the flask and the chips.

W2 = Weight of the sample

\subsection{Determination of total carbohydrate content (Dubois method)}

The sugar content was determined by using modified method of (Dubois et al., 1956). Approximately $0.1 \mathrm{~g}$ of pulverized sample which was measured by the analytical balance (AGN220C max $220 \mathrm{~g}$, d= $0.0001 \mathrm{~g}$ ) was hydrolyzed at $100{ }^{0} \mathrm{C}$ in a water bath for 2 hours with $50 \mathrm{ml}$ of $2 \mathrm{M} \mathrm{HCl}$ after which neutralized by $50 \mathrm{ml}$ of $2 \mathrm{M} \mathrm{NaOH}$. The neutralized solution was filtered through Whatman No. 41 paper. $500 \mu \mathrm{l}$ of filtrate and $500 \mu \mathrm{l}$ of $20 \%$ phenol solution was added into a test tube followed by $2.5 \mathrm{ml}$ concentrated sulfuric acid (Analytical grade reagent). Mixture was incubated for $10 \mathrm{~min}$ in room temperature. After incubation mixture was vortex vigorously for 10 seconds. Then solution was again incubated in room temperature for $15 \mathrm{~min}$, followed by $37{ }^{0} \mathrm{C}$ incubator for 30 minutes. Absorbance was measured at a wavelength of $490 \mathrm{~nm}$ using UV mini-1240 Spectrophotometer. Blank solution was prepared following the same procedure as above replacing the sample with distilled water. The standard curve was drawn for $\mathrm{D}$ - Glucose from regression analysis using the software MINITAB R 17 by measuring the absorbance values corresponding to D-Glucose concentration. Experiment was triplicated for all the samples and standards.

\subsection{Determination of total fibre content}

Total fibre content was calculated by the following equation;

Percentage of fibre content $(\mathrm{m} / \mathrm{m})=100-(\mathrm{A}+\mathrm{B}+\mathrm{C}+\mathrm{D}+\mathrm{E})$

$\mathrm{A}=$ Percentage moisture content of the sample

$\mathrm{B}=$ Percentage total fat content of the sample

$\mathrm{C}=$ Percentage crude protein content of the sample

$\mathrm{D}=$ Percentage total carbohydrate content of the sample

$\mathrm{E}=$ Percentage total ash content of the sample

\subsection{Determination of sulphate content}

Sulphate was determined using modified AOAC Gravimetric method (AOAC,1995) with minor modifications. Dry seaweed sample of $0.5 \mathrm{~g}$ was transferred into a beaker with $10 \mathrm{ml}$ of concentrated $\mathrm{HNO}_{3}$. The beaker was placed in hot plate and it was heated at $123{ }^{\circ} \mathrm{C}$ in a fume hood for $30 \mathrm{~min}$ to have the final volume of digest as 2-3 ml. After cooling the sample in fume hood 2- 3 drops of $40 \% \mathrm{HCHO}$ solution were added to reduce the excess $\mathrm{HNO}_{3}$. The mixture was filtered into $250 \mathrm{ml}$ conical flask and 0.5 $\mathrm{ml}$ concentrated $\mathrm{HCl}$ was added followed by distilled water to bring the volume to $200 \mathrm{ml}$. The solution was heat to boiling and $10 \mathrm{ml}$ of $0.25 \mathrm{M} \mathrm{BaCl}_{2}$ was added drop wise with constant stirring for 5 min and kept aside for $5 \mathrm{~h}$ in a warm place, The $\mathrm{BaSO}_{4}$ solution was filtered with ash less Whatman filter paper and precipitate was ashed in crucibles in muffle furnace at $560{ }^{\circ} \mathrm{C}$ for $24 \mathrm{~h}$. The crucibles were transferred 
Jayakody et al. /Journal of Tropical Forestry and Environment Vol. 9, No. 02 (2019) 93-100

to desiccator for cooling and weighed to determine the weight of $\mathrm{BaSO}_{4}$. The percentage sulphate was calculated from the following equation;

Sulphate $(\% \mathrm{DB})=\frac{(0.4116 \times \mathrm{A})}{\mathrm{B}} \times 100$

$\mathrm{A}=$ Weight of $\mathrm{BaSO}_{4}$

$\mathrm{B}=$ Weight of the sample

\subsection{Statistical analysis}

Analysis was performed in duplicates except for the crude protein content. Mean values of moisture, fat, protein, carbohydrate, ash and fibre were analyzed by one-way ANOVA and Tukey comparison at $\mathrm{p}<$ 0.05 by MINITAB 17 to detect significant differences among groups.

\section{Results}

Table 1: Moisture, fat, and protein contents of Chnoospora minima, Porphyra sp., and Ulva fasciata

\begin{tabular}{lccc}
\hline Seaweed variety & Moisture (\%) & Fat $(\%)$ & Protein $(\%)$ \\
\hline Chnoospora minima & $13.24 \pm 0.20^{\mathrm{c}}$ & $0.21 \pm 0.11^{\mathrm{a}}$ & $13.70 \pm 0.2^{\mathrm{b}}$ \\
Porphyra sp. & $14.30 \pm 0.14^{\mathrm{b}}$ & $0.19 \pm 0.03^{\mathrm{a}}$ & $21.14 \pm 0.04^{\mathrm{a}}$ \\
Ulva fasciata & $18.11 \pm 0.01^{\mathrm{a}}$ & $0.28 \pm 0.05^{\mathrm{a}}$ & $11.84 \pm 0.1^{\mathrm{c}}$
\end{tabular}

Values are means \pm SD of two determinations. Different letters a, b and $\mathrm{c}$ in the same column indicate significant difference $(\mathrm{p}<0.05)$

Table 2 : Carbohydrate, ash and fibre contents of Chnoospora minima, Porphyra sp., and Ulva fasciata

\begin{tabular}{llll}
\hline Seaweed variety & Carbohydrate $(\%)$ & ash $(\%)$ & Fibre $(\%)$ \\
\hline Chnoospora minima & $3.87 \pm 0.66^{\mathrm{c}}$ & $17.20 \pm 0.24^{\mathrm{a}}$ & $51.77 \pm 1.03^{\mathrm{a}}$ \\
Porphyra sp. & $20.59 \pm 0.24^{\mathrm{a}}$ & $5.4 \pm 0.7^{\mathrm{b}}$ & $38.24 \pm 1.08^{\mathrm{c}}$ \\
Ulva fasciata & $7.68 \pm 1.16^{\mathrm{b}}$ & $18.05 \pm 0.21^{\mathrm{a}}$ & $44.04 \pm 0.77^{\mathrm{b}}$
\end{tabular}

Values are means \pm SD of two determinations. Different letters a, b and $c$ in the same column indicate significant difference $(\mathrm{p}<0.05)$

Table 3 : Sulphate content of Chnoospora minima, Porphyra sp. and Ulva fasciata

Seaweed variety $\quad$ Sulphate content (\%)


Chnoospora minima

Porphyra sp.

Ulva fasciata

Values are means \pm SD of two determinations. Different letters $a, b$ and $c$ in the same column indicate significant difference $(\mathrm{p}<0.05)$

\section{Discussion}

The results revealed that the highest composition of analyzed seaweed varieties is comprised of fibre. The fibre content of the analyzed seaweed varieties are significantly different $(\mathrm{p}<0.05)$ from each other. Chnoospora minima has the highest fibre content among all the 3 varieties. Dietary fibre is defined as an indigestible fraction which contains oligosaccharides and resistant starches, resistant proteins, and associated compounds such as polyphenols (Jiménez-Escrig and Sánchez-Muniz, 2000). Generally fibre is not digested by the digestive enzymes. But this undigested portion will supply many health benefits to the body. Fibre adds bulk to the diet, fibre will also attracts water and turns to gel during digestion there by traps carbohydrates and slows absorption of glucose hence it lowers variance in blood sugar levels, it also lowers total and LDL cholesterol etc. (Dhingra et al., 2011). Thus consumption of fibre rich food will enable the consumers to lead a healthy life.

The results of the analysis revealed that the crude protein content of the samples significantly different among each other $(\mathrm{p}<0.05)$. Highest protein content was recorded in the red algae variety porphyra sp. $(21.14 \pm 0.04)$. while lowest in the green algae $U$. fasciata $(11.84 \pm 0.1)$ The results obtained from the analysis agree with Fleurence, Morançais and Dumay, (2018) which states that the protein content of marine algae differs according to the species and low for brown seaweeds $(3 \pm 15 \%$ of dry weight), moderate for green algae $(9 \pm 26 \%$ of dry weight $)$ and protein content is high for red seaweeds (maximum 47\% of dry weight) (Fleurence, Morançais and Dumay, 2018).

The fat content of the all the analyzed seaweed varieties were not significantly different $(\mathrm{p}>0.05)$. The data of fat content $(\%)$ remained in the range $(<4 \%$ on DW) as reported earlier for various macro algal species. (Kumari et al., 2010).

The carbohydrate content (\%) of Chnoospora minima, Porphyra sp. and Ulva fasciata is represented in Table 2. According to the results Carbohydrate contents of the 3 seaweed varieties are significantly different $(\mathrm{p}<0.05)$ recording the highest carbohydrate content $20.59 \pm 0.24$ in Porphyra sp. The phenol-sulfuric acid method is used to determine the Carbohydrate content of the samples. It is a simple and rapid colorimetric method to determine total carbohydrates in a sample. This method determines virtually all classes of carbohydrates, including monosaccharides, disaccharides, oligosaccharides, and polysaccharides. Although the method detects almost all carbohydrates, the absorptivity of the different carbohydrates varies. Thus, unless a sample is known to contain only one carbohydrate, the results must be expressed arbitrarily in terms of one carbohydrate. In this method, the concentrated sulfuric acid breaks down any polysaccharides, oligosaccharides, and disaccharides to monosaccharide. Pentoses (5-carbon compounds) are then dehydrated to furfural, and hexoses (6-carbon compounds) to hydroxymethyl furfural. These compounds then react with phenol to produce a yellowgold color. For products that are high in hexose sugars, glucose is commonly used to create the standard curve, and the absorption is measured at $490 \mathrm{~nm}$. The color for this reaction is stable for several hours, it is said that the accuracy of the method is within $\pm 2 \%$ under proper conditions. (Nielsen, 2009). 
Jayakody et al. /Journal of Tropical Forestry and Environment Vol. 9, No. 02 (2019) 93-100

The Table 3 represents the sulphate content of the 3 seaweed varieties. The sulphate contents of the 3 seaweed varieties are significantly different $(\mathrm{p}<0.05)$ and the highest sulphate content has been recorded in $U$. fasciata as $4.54 \pm 0.06$

According to certain research articles Sulphates and chlorides are the main anions found in seaweeds. These are important constituents of charged polysaccharides in marine algae which related to high salt concentration in the environment. (Gómez-Ordóñez, Alonso and Rupérez, 2010). Research report by Rupérez and Saura-Calixto, (2001) has reported that physicochemical properties of dietary fibre in edible seaweeds are related to the hydrophilic nature of the charged polysaccharides. Sulphated polysaccharides from edible marine algae are not toxic for humans and, especially fucans and alginic acid derivatives, are known to exhibit different biological properties, such as anticoagulant, antiinflammatory, antiviral, or anti- tumoral activities. (Rupérez, Ahrazem and Leal, 2002). Also, sulphated polysaccharides from brown and red seaweeds have been reported to exhibit antioxidant capacity in vitro and potentially could be used as natural antioxidants by the food industry (Rupérez, Ahrazem and Leal, 2002).

\section{Conclusion}

All the 3 seaweed varieties, Chnoospora minima, Porphyra sp. and Ulva fasciata are very good sources of dietary fibre while all the 3 seaweed varieties are poor in fat. The three varieties are also moderately good sources of carbohydrates, protein and minerals with a highest carbohydrate and protein content in Porphyra sp. among the three.

\section{Acknowledgment}

The authors wish to thank department of Food Science and Technology of University of Sri Jayewardenepura for supplying necessary equipment and chemicals for the research.

\section{References}

Chan, C., Ho, C. and Phang, S., 2006. Trends in seaweed research. Trends in Plant Science, 11:165-166.

Dawczynski, C., Schubert, R. and Jahreis, G., 2007. Amino acids, fatty acids, and dietary fibre in edible seaweed products. Food Chemistry, 103:891-899.

Dhingra, D., Michael, M., Rajput, H. and Patil, R., 2011. Dietary fibre in foods: a review. Journal of Food Science and Technology, 49:255-266.

DuBois, M., Gilles, K., Hamilton, J., Rebers, P. and Smith, F., 1956. Colorimetric Method for Determination of Sugars and Related Substances. Analytical Chemistry, 28:350-356.

Fleurence, J., Morançais, M. and Dumay, J., 2018. Seaweed proteins. Proteins in Food Processing, pp.245-262.

Gómez-Ordóñez, E., Alonso, E. and Rupérez, P., 2010. A simple ion chromatography method for inorganic anion analysis in edible seaweeds. Talanta, 82:1313-1317.

Gupta, S. and Abu-Ghannam, N., 2011. Recent developments in the application of seaweeds or seaweed extracts as a means for enhancing the safety and quality attributes of foods. Innovative Food Science \& Emerging Technologies, 12:600-609. 
Jiménez-Escrig, A. and Sánchez-Muniz, F., 2000. Dietary fibre from edible seaweeds: Chemical structure, physicochemical properties and effects on cholesterol metabolism. Nutrition Research, 20:585-598.

Kumari, P., Kumar, M., Gupta, V., Reddy, C. and Jha, B., 2010. Tropical marine macroalgae as potential sources of nutritionally important PUFAs. Food Chemistry, 120:749-757.

Marsham, S., Scott, G. and Tobin, M., 2007. Comparison of nutritive chemistry of a range of temperate seaweeds. Food Chemistry, 100:1331-1336.

Matanjun, P., Mohamed, S., Mustapha, N. and Muhammad, K., 2008. Nutrient content of tropical edible seaweeds, Eucheuma cottonii, Caulerpa lentillifera and Sargassum polycystum. Journal of Applied Phycology, 21:75-80.

Nielsen, S., 2009. Phenol-Sulfuric Acid Method for Total Carbohydrates. Food Analysis Laboratory Manual, pp.47-53.

Rupérez, P., Ahrazem, O. and Leal, J., 2002. Potential Antioxidant Capacity of Sulfated Polysaccharides from the Edible Marine Brown SeaweedFucus vesiculosus. Journal of Agricultural and Food Chemistry, 50:840-845.

Rupérez, P. and Saura-Calixto, F., 2001. Dietary fibre and physicochemical properties of edible Spanish seaweeds. European Food Research and Technology, 212:349-354.

Wong, K. and Cheung, P., 2000. Nutritional evaluation of some subtropical red and green seaweeds. Food Chemistry, 71:475-482. 